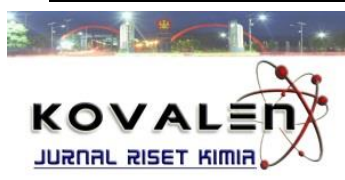

\title{
PEMANFAATAN ARANG AKTIF KULIT BUAH SUKUN (Artocarpus altilis (Parkinson) Fosberg) SEBAGAI ADSORBEN DALAM PERBAIKAN MUTU MINYAK JELANTAH
}

\author{
[Utilization of Breadfruit (Artocarpus altilis (Parkinson) Fosberg) Peel Activated \\ Charcoal as Adsorbent in Quality Improvement of Used Cooking Oil]
}

\author{
Nyoman Suartini ${ }^{1 *}$, Jamaluddin $^{1}$, Ihwan $^{1}$ \\ 1)Jurusan Farmasi, Fakultas MIPA, Universitas Tadulako, \\ Jln. Soekarno-Hatta Km. 9, Palu, Sulawesi Tengah \\ "Coresponding Author: nyomansuartini94@gmail.com
}

Diterima 12 Januari 2018, Disetujui 28 Mei 2018

\begin{abstract}
Cooking oil is a basic human need. The high level of cooking oil consumption causes the amount of used cooking oil to increase. Used cooking oil to be reusable, purification by using activated charcoal adsorbent is needed. The aim of this research is to know the percentage (\%) change of free fatty acid, peroxide value, and oil color after purification with activated charcoal of breadfruit (Artocarpus altilis) peel and comparison of the result with activated charcoal in market. This research used titration method to determine free fatty acid content and peroxide value and spectrophotometric method to determine oil quality by looking at oil color. The results showed the change of oil color from dark to bright with the decrease of free fatty acid content, peroxide value, and absorbance after purified with activated charcoal of breadfruit peel for $51,04 \%, 33,11 \%$, and 0,898 Abs (chicken), 48,38\%, 29,32\%, and $0,721 \mathrm{Abs}$ (fresh fish), 52,34\%, 37,92\%, and 1,790 Abs (dried fish), and also $50,16 \%, 35,41 \%$, and 0,231 Abs (Tempe-tofu), respectively. The statistical results showed that there was a significant difference between activated charcoal of breadfruit peel adsorbent and activated charcoal on the market on the decrease of free fatty acid content in cooking oil from dried fish fryers and peroxide value on cooking oil from chicken frying, fresh fish, and dried fish.
\end{abstract}

Keywords: Activated Charcoal, Breadfruit Peel, Adsorbent, Used cooking oil

\begin{abstract}
ABSTRAK
Minyak goreng merupakan kebutuhan pokok manusia. Tingginya tingkat konsumsi minyak goreng menyebabkan jumlah minyak jelantah semakin meningkat. Minyak jelantah agar dapat dimanfaatkan kembali, perlu dilakukan proses pemurnian dengan menggunakan adsorben arang aktif. Tujuan penelitian untuk mengetahui persentase (\%) perubahan kadar asam lemak bebas, bilangan peroksida, dan perubahan warna minyak setelah dimurnikan dengan arang aktif kulit buah sukun (Artocarpus altilis) serta perbandingan hasilnya dengan arang aktif di pasaran. Penelitian ini menggunakan metode titrasi untuk menentukan kadar asam lemak bebas dan bilangan peroksida serta metode spektrofotometri untuk menentukan kualitas minyak dengan melihat warna minyak. Hasil penelitian menunjukan terjadinya perubahan warna minyak dari gelap menjadi cerah dengan penurunan kadar asam lemak bebas, bilangan peroksida, serta absorbansi setelah dimurnikan dengan arang aktif kulit buah sukun berturut-turut sebesar $51,04 \%, 33,11 \%$, dan 0,898 Abs (ayam), 48,38\%, 29,32\%, dan 0,721 Abs (ikan basah), 52,34\%, 37,92\%, dan 1,790 Abs (ikan kering), serta $50,16 \%, 35,41 \%$, dan 0,231 Abs (tahu-tempe). Hasil statistik menunjukan terdapat perbedaan signifikan antara adsorben arang aktif kulit buah sukun dengan arang aktif di pasaran pada penurunan kadar asam lemak bebas pada minyak jelantah dari pengorengan ikan kering serta bilangan peroksida pada minyak jelantah dari penggorengan ayam, ikan basah, dan ikan kering.
\end{abstract}

Kata Kunci : Arang Aktif, Kulit Buah Sukun, Adsorben, Minyak Jelantah 


\section{LATAR BELAKANG}

Minyak goreng yang berasal dari miyak sawit banyak difungsikan sebagai media pengolahan bahan makanan dan telah menjadi salah satu kebutuhan pokok manusia. Penggunaan minyak goreng akan menghasilkan minyak bekas penggorengan atau dikenal minyak jelantah. Tingginya tingkat konsumsi minyak goreng di Indonesia mendorong produksi minyak goreng juga semakin meningkat dan akhirnya menghasilkan minyak jelantah dalam jumlah banyak. Meningkatnya jumlah minyak jelantah juga tidak lepas dari semakin berkembangnya bisnis makanan gorengan.

Umumnya sebagian masyarakat menggunakan minyak goreng secara secara berulang-ulang sampai warnanya coklat tua atau hitam, tanpa pernah diganti dan hanya menambah sejumlah minyak segar. Penggunaan minyak goreng secara berulang akan menyebabkan perubahan kualitas minyak karena terjadi oksidasi dan tentunya menimbulkan kerusakan (Nasir, 2014). Akibat oksidasi minyak goreng bekas, maka akan terjadi kerusakan nilai gizi tekstur, dan flavor dari bahan pangan (Ketaren, 2008). Masyarakat di Indonesia cenderung memanfaatkan minyak goreng secara berulang kali demi menghemat biaya tanpa mempertimbangkan resiko bagi kesehatan, seperti menjadi pemicu kanker dan kerongkongan gatal atau serak (Istighfaro, 2010).

Penelitian Fadlia (2016), sebaiknya proses penggorengan dilakukan tidak melebihi 4 kali ulangan. Hasil penelitiannya menunjukan bahwa kadar asam lemak bebas pada penggorengan ke-1 sampai ke4 dengan kadar 0,15\% - 0,26\% masih memenuhi standar SNI, tetapi kadar asam lemak bebas pada penggorengan ke-5 sampai ke-7 dengan kadar 0,33\% - 0,50\% sudah melebihi kadar yang disyaratkan oleh SNI yaitu $0,3 \%$. Sedangkan untuk bilangan peroksida pada penggorengan ke-1 sampai ke-6 dengan kadar 2,87 meq/kg - 7,58 $\mathrm{meq} / \mathrm{kg}$ masih memenuhi standar yang ditetapkan oleh SNI, tetapi bilangan peroksida pada penggorengan ke-7 (12,55 $\mathrm{meq} / \mathrm{kg}$ ) sudah melebihi kadar yang ditetapkan oleh SNI yaitu $10 \mathrm{meq} / \mathrm{kg}$.

Faktor lain yang menyebabkan kerusakan mutu minyak goreng adalah jenis bahan pangan yang digoreng. Abdullah (2007) melaporkan bahwa penggunaan minyak untuk menggoreng tahu akan mengakibatkan kerusakan minyak lebih cepat daripada penggunaan untuk menggoreng tempe dan pisang. Hasil penelitiannya menyatakan bahwa minyak gorengan tahu pada pengulangan pertama telah mengalami kerusakan, sedangkan minyak hasil gorengan pisang dan tempe baru mengalami kerusakan pada penggorengan kedua dan setelah penggunaan ketiga akan terjadi dekomposisi peroksida menjadi senyawa keton dan aldehid.

Minyak goreng bekas atau minyak jelantah dapat digunakan kembali setelah dilakukan pemurnian. Pemurnian ini dimaksudkan untuk memperbaiki flavor 
minyak, seperti menghilangkan rasa serta aroma yang tidak sedap dan warna yang tidak menarik, serta memperpanjang usia guna minyak (Ketaren, 2008). Sehingga dapat meningkatkan kualitas minyak goreng bekas dan lebih aman untuk dikonsumsi kembali serta tidak menimbulkan dampak yang buruk bagi kesehatan. Pemurnian atau peningkatan kualitas minyak goreng bekas dapat dilakukan dengan cara adsorbs menggunakan adsorben. Adsorben akan menyerap zat warna pada minyak, suspensi koloid, serta hasil degradasi minyak (Aji and Hidayat, 2011). Adsorben yang biasa digunakan adalah arang aktif. Arang aktif dapat berfungsi sebagai adsorben karena memiliki struktur pori internal dan memiliki luas permukaan total antara $300-3500 \mathrm{~m}^{2} / \mathrm{g}$ dan (Jamilatun and Setyawan, 2014). Daya serap arang aktif dapat mencapai 25-1000\% terhadap berat arang aktif (Sembiring and Sinaga, 2003).

Penelitian tentang penggunaan arang aktif sebagai adsorben pemurnian minyak jelantah telah banyak dikembangkan. Hartini and Yustinah (2011) telah melakukan pemurnian minyak goreng bekas dengan menggunakan adsorben 10 gram arang aktif dari sabut kelapa dan terjadi penurunan bilangan peroksida dari $12,87 \mathrm{meq} / \mathrm{kg}$ menjadi $1,99 \mathrm{meq} / \mathrm{kg}$ pada minyak hasil pemurnian. Arang aktif dapat diperoleh dari biomassa, salah satunya adalah kulit buah sukun.

Sukun adalah jenis tumbuhan tropis dan sangat banyak dijumpai di Indonesia, khususnya di Sulawesi Tengah.
Produktivitas buah sukun cukup tinggi dalam setahun diperoleh buah sukun tiap pohon sebanyak 400 buah pada umur 5-6 tahun dan 700-800 buah pada umur 8 tahun (Sukriya, 2009). Hal ini menyebabkan terjadinya peningkatan jumlah limbah kulit buah sukun. Oleh karena itu, diperlukan adanya pemanfaatan limbah kulit buah sukun salah satunya sebagai arang aktif.

Berdasarkan penelitian Pratiwi (2011), menunjukan bahwa kulit buah sukun mengandung selulosa dengan kadar $17,59 \%$. Selulosa merupakan polisakarida yang mengandung gugus $-\mathrm{OH}$ sehingga dapat digunakan sebagai adsorben. Priyantha et al. (2013), melakukan penelitian bioremediasi ion $\mathrm{Cu}$ (II) dan $\mathrm{Cd}$ (II) dari medium cair menggunakan adsorben dari limbah kulit dan inti buah sukun. Hasil penelitian menunjukan kemampuan biosorpsi antara kulit dan inti buah sukun terhadap ion logam berat $\mathrm{Cu}$ (II) dan Cd (II) begitu kuat sehingga keseimbangan adsorpsi mencapai efisien.

Oleh karena itu, perlu dilakukan pemurnian minyak goreng bekas dengan menggunakan adsorben arang aktif dari kulit buah sukun. Tujuan yaitu mengetahui kemampuan arang aktif dari kulit buah sukun untuk menurunkan Asam Lemak Bebas, Bilangan Peroksida (PV), dan warna gelap pada minyak goreng bekas.

\section{METODE PENELITIAN}

\section{Bahan dan Peralatan}

Bahan yang digunakan pada penelitian ini yaitu kulit buah sukun, minyak goreng 
baru, minyak jelantah (minyak goreng bekas pengorengan ayam, tahu-tempe, ikan basah, dan ikan kering), arang aktif di pasaran, $\mathrm{H}_{3} \mathrm{PO}_{4} 1 \mathrm{M}$, aquadest, indikator fenolftalein, natrium tiosulfat $0,1 \mathrm{~N}$, larutan pati $1 \%$, larutan $\mathrm{KI}$ jenuh, larutan asam

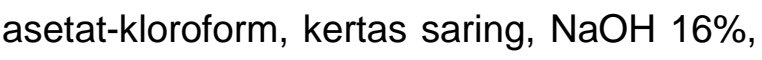
etanol $96 \%, \mathrm{KOH} 0,1 \mathrm{~N}$, dan aluminium foil.

Peralatan yang digunakan, yaitu tanur (LabTech Electric Muffle Furnace LEF103S), oven (SL ${ }^{\circledR} \mathrm{El}$ Lab), cawan porselin, lumpang dan alu, ayakan 100 mesh, neraca analitik (Citizen), corong, buret (Iwaki Pyrex ${ }^{\circledR}$ ), klem dan statif, gelas kimia (Iwaki Pyrex $^{\circledR}$ ), corong (Iwaki Pyrex ${ }^{\circledR}$ ), corong pisah (Iwaki Pyrex $^{\circledR}$ ), hotplate, batang pengaduk, termometer, spektrofotometer UV/Vis, kuvet, erlenmeyer (Iwaki Pyrex ${ }^{\circledR}$ ), pipet tetes, labu ukur (Iwaki Pyrex ${ }^{\circledR}$ ), gelas ukur (Iwaki Pyrex ${ }^{\circledR}$ ), dan stirrer.

\section{Prosedur Penelitian}

\section{Penyediaan Minyak Jelantah}

Minyak goreng yang digunakan adalah minyak jelantah yang diperoleh dari penggunaan sendiri yang telah digunakan untuk menggoreng ayam selama beberapa kali pengulangan menggunakan minyak goreng yang sama, temperatur yang sama, dan lama penggorengan yang sama. Pengujian kadar asam lemak bebas, bilangan peroksida, dan warna minyak dilakukan setiap kali selesai proses penggorengan. Proses ini dilakukan hingga minyak goreng mengalami kerusakan pada tingkat yang tidak memenuhi standar minyak goreng. Prosedur tersebut diulangi untuk perlakuan tahu-tempe, ikan basah, dan ikan kering.

\section{Preparasi Sampel Kulit Buah Sukun}

Kulit buah sukun yang digunakan adalah kulit buah sukun yang sudah tua (umur buah \pm 3 bulan). Kulit buah sukun dipotong-potong kemudian dibersihkan dari sisa-sisa kotoran dengan air bersih.

\section{Pembuatan Arang Aktif Kulit Buah Sukun}

A. Dehidrasi (Wiyaningsih, 2010)

Kulit buah sukun yang telah dibersihkan kemudian dikeringkan dalam oven pada suhu $105^{\circ} \mathrm{C}$ selama 24 jam.

B. Karbonisasi (Nasir, 2014)

Kulit buah sukun dimasukan ke dalam tanur selama 2 jam pada suhu $400^{\circ} \mathrm{C}$, sampai kulit buah sukun menjadi arang. Arang yang diperoleh kemudian didinginkan, selanjunya, arang dihaluskan dengan menggunakan lumpang dan diayak menggunakan ayakan berukuran 100 mesh.

C. Aktifasi (Jaya, 2014)

Selanjutnya 25 gram arang dimasukan ke dalam gelas kimia $500 \mathrm{~mL}$ kemudian ditambahkan $100 \mathrm{~mL}$ larutan $\mathrm{H}_{3} \mathrm{PO}_{4} 1 \mathrm{M}$ dan direndam selama 24 jam. Selanjutnya, arang disaring dan dicuci dengan aquadest hingga mencapai $\mathrm{pH}$ netral. Selanjutnya dimasukan ke dalam oven dengan suhu $100^{\circ} \mathrm{C}$ selama 2 jam.

\section{Pemurnian Minyak Jelantah}

A. Proses Penghilangan Bumbu (Despicing) (Wiyaningsih, 2010).

Ditimbang sebanyak 500 gram minyak goreng bekas kemudian 
ditambahkan air dengan komposisi minyak : air (1:1), masukkan ke dalam beaker glass $1000 \mathrm{~mL}$. Selanjutnya dipanaskan sampai air dalam beaker glass tinggal setengahnya. Diendapkan dalam corong pisah selama 1 jam, kemudian fraksi air pada bagian bawah dipisahkan sehingga diperoleh fraksi minyak, setelah itu dilakukan penyaringan dengan kertas saring untuk memisahkan kotoran yang tersisa.

B. Proses Netralisasi (Wiyaningsih, 2010)

Minyak hasil despicing sebanyak 300 gram dipanaskan sampai temperatur $35^{\circ} \mathrm{C}$, kemudian ditambahkan $12 \mathrm{~mL}$ larutan $\mathrm{NaOH} 16 \%$, diaduk campuran selama 10 menit pada temperatur $40^{\circ} \mathrm{C}$, selanjutnya didinginkan sampai terbentuk sabun, kemudian disaring menggunakan kertas saring.

C. Proses Pemucatan (Bleaching) (Wiyaningsih, 2010)

Minyak goreng hasil netralisasi sebanyak 200 gram dipanaskan sampai suhu $70^{\circ} \mathrm{C}$, dimasukan masing-masing serbuk arang aktif kulit buah sukun dan arang aktif pasaran dengan jumlah 0,1$0,2 \%$ dari berat minyak, kemudian ditingkatkan suhunya $100^{\circ} \mathrm{C}$ pada 5 menit petama dan dilakukan pengadukan dengan magnetik stirer selama 60 menit. Selanjutnya disaring dengan kertas saring.

\section{Parameter Pengujian}

1. Warna (Pakiding, 2014)

Warna minyak diukur dengan menggunakan spektrofotometer UV/Vis.
Sampel minyak goreng dimasukan ke dalam kuvet dandiukur absorbansinya pada panjang gelombang $448 \mathrm{~nm}$.

2. Kadar Bilangan Peroksida (Rohman and Sumantri, 2007)

Sebanyak 5 gram sampel minyak ditimbang dan dimasukkan dalam erlenmeyer $250 \mathrm{~mL}$ dan ditambah $30 \mathrm{~mL}$ larutan asam asetat-kloroform (3:2). Larutan digoyangkan sampai bahan terlarut semua lalu ditambah $0,5 \mathrm{~mL}$ larutan jenuh $\mathrm{Kl}$. Larutan selanjutnya didiamkan selama 1 menit dengan kadangkala digoyang kemudian ditambah $30 \mathrm{~mL}$ aquadest. Campuran dititrasi dengan larutan baku natrium tiosulfat 0,1 $\mathrm{N}$ sampai warna kuning hampir hilang lalu ditambah $0,5 \mathrm{~mL}$ larutan pati $1 \%$. Titrasi dilanjutkan sampai warna biru tepat hilang. Dilakukan juga titrasi blanko dengan cara yang sama (banyaknya volume larutan baku tiosulfat untuk titrasi blanko tidak lebih dari $0,1 \mathrm{~mL}$ ). Bilangan peroksida dihitung dengan menggunakan persamaan sebagai berikut:

Bilangan peroksida $=\frac{1000 \times \mathrm{N} \times(\mathrm{V} 0-\mathrm{V} 1)}{\left(\mathrm{mek}_{2} / \mathrm{Kg}\right)=\mathrm{W}} \ldots .(1)$ Keterangan:

$\mathrm{N}$ : Normalitas larutan standar natrium tiosulfat $(\mathrm{N})$

$\mathrm{V}_{0}$ : Volume larutan natrium tiosulfat yang digunakan untuk titrasi sampel $(\mathrm{mL})$

$\mathrm{V}_{1}$ : Volume larutan natrium tiosulfat yang digunakan untuk titrasi blanko $(\mathrm{mL})$

W : Bobot contoh (g)

3. Kadar Asam Lemak Bebas (Anonim, 2012)

Timbang $10 \mathrm{~g}$ sampai dengan $50 \mathrm{~g}$ contoh (W) ke dalam erlenmeyer. Larutkan dengan $50 \mathrm{~mL}$ etanol hangat 
dan tambahkan 5 tetes larutan fenolftalein. Titrasi larutan tersebut dengan $\mathrm{KOH}$ 0,1 $\mathrm{N}$ sampai terbentuk warna merah muda (warna merah muda bertahan selama 30 detik). Catat volume larutan $\mathrm{NaOH}$ yang digunakan.

Kadar asam lemak bebas dihitung dengan menggunakan persamaan sebagai berikut:

$$
F F A=\frac{25,6 \times \vee \times N}{W}
$$

Keterangan :

FFA : Asam lemak bebas (sebagai asam palmitat)

$\mathrm{V} \quad$ : Volume larutan $\mathrm{KOH}$ yang digunakan $(\mathrm{mL})$

$\mathrm{N}:$ : Normalitas larutan $\mathrm{KOH}(\mathrm{N})$

W : Bobot contoh yang diuji (gram)

\section{HASIL DAN PEMBAHASAN}

Minyak jelantah merupakan minyak yang dihasilkan dari proses penggorengan lebih dari 5 kali pengulangan, tanpa pernah diganti sehingga warna minyak menjadi kecoklatan atau hitam. Minyak yang digunakan lebih dari 5 kali pengulangan dapat mengakibatkan kerusakan tekstur dan flavor serta nilai gizi dari bahan pangan yang digoreng. Minyak jelantah agar dapat dimanfaatkan kembali, perlu dilakukan proses pemurnian sehingga dapat meningkatkan mutu minyak jelantah.

Penelitian ini bertujuan untuk memperbaiki mutu minyak jelantah dengan menggunakan metode adsorpsi. Salah satu jenis adsorben yang biasa digunakan yaitu arang aktif. Bahan baku pembuatan arang aktif dalam penelitian ini adalah kulit buah sukun. Menurut penelitian Pratiwi (2011), menunjukan bahwa kulit buah sukun mengandung selulosa dengan kadar $17,59 \%$. Selulosa merupakan polisakarida yang mengandung gugus $-\mathrm{OH}$ sehingga dapat digunakan sebagai adsorben. Gugus $-\mathrm{OH}$ dapat bereaksi dengan gugus $-\mathrm{COOH}$ dari asam lemak bebas yang ada di minyak jelantah, sehingga dapat berperan untuk menurunkan kadar asam lemak bebas pada minyak goreng bekas serta memperbaiki fisik dari minyak jelantah (Ratnawaty and Indrawati, 2016). Menurut Siburian et al. (2014), gugus $-\mathrm{OH}$ merupakan indikasi melekatnya senyawa polar peroksida. Molekul-molekul kecil peroksida memiliki gugus polar sehingga dapat berinteraksi atau terikat dengan selulosa yang kaya akan gugus hidroksil (-OH) yang polar (Rahayu et al., 2014). Selain itu, zat warna juga mengandung gugus-gugus yang dapat bereaksi dengan gugus $\mathrm{OH}$ dari selulosa. Zat warna reaktif dapat mewarnai serat selulosa dalam kondisi tertentu dan membentuk senyawa dengan ikatan kovalen atau ikatan hidrogen dengan selulosa (Irawan et al., 2013).

Kulit buah sukun terlebih dahulu dibersihkan dan dikeringkan dalam oven untuk mengurangi kandungan air yang terdapat pada sampel. Selanjutnya kulit buah sukun dikarbonisasi untuk menghilangkan komponen-komponen yang terkandung didalam sampel sehingga diperoleh butiran arang. Pada tahap ini terjadi proses pirolisis, yaitu proses penguraian senyawa organik (selulosa, lignin, dan hemiselulosa) menjadi arang, karbon dioksida, uap air, dan minyak 
berwarna hitam. Senyawa hasil pirolisis yang mudah menguap akan terlepas dan unsur karbon serta senyawa anorganik yang tertinggal disebut arang (Yuliyati et al., 2017). Arang yang diperoleh kemudian dihaluskan dan diayak untuk memperoleh ukuran partikel serbuk arang aktif yang seragam. Selanjutnya, dilakukan proses aktivasi yang bertujuan untuk memperbesar pori yaitu dengan cara memecahkan ikatan hidrokarbon atau mengoksidasi molekulmolekul permukaan sehingga karbon mengalami perubahan sifat, baik fisika maupun kimia, yaitu luas permukaannya bertambah besar dan berpengaruh terhadap daya adsorpsi (Sembiring and Sinaga, 2003). Menurut penelitian Esterlita and Herlina (2015) menunjukan bahwa agen aktivator yang terbaik yaitu $\mathrm{H}_{3} \mathrm{PO}_{4}$ dengan konsentrasi $1 \mathrm{M}$. Kemudian endapan yang dihasilkan dari proses aktivasi dipisahkan dan dicuci dengan aquadest hingga mencapai $\mathrm{pH}$ netral, selanjutnya dikeringkan kembali dalam oven untuk menghilangkan air yang terperangkap dalam pori-pori.

Tahap pertama proses pemurnian yaitu proses penghilangan bumbu (Despicing) yang bertujuan menghilangkan partikel halus tersuspensi atau terbentuk koloid seperti protein, karbohidrat, garam, gula, serta bumbu rempah-rempah yang digunakan dalam menggoreng bahan pangan (Taufiq, 2007). Selanjutnya dilakukan proses netralisasi yang bertujuan untuk memisahkan asam lemak bebas dari minyak, dengan cara mereaksikan asam lemak bebas dengan basa atau pereaksi lainnya. Netralisasi dengan menggunakan $\mathrm{NaOH}$ banyak dilakukan dalam skala industri, karena lebih efisien dan lebih murah dibandingkan dengan cara netralisasi lainnya. Selanjutnya yaitu tahap bleaching yang bertujuan untuk menghilangkan zat-zat warna yang tidak disukai dalam minyak. Proses ini dilakukan dengan mencampur minyak dengan sejumlah kecil adsorben. Zat warna dalam minyak akan diserap oleh permukaan adsorben dan juga suspensi koloid serta hasil degradasi minyak seperti peroksida. Daya adsorpsi arang aktif disebabkan karena arang mempunyai poripori dalam jumlah besar dan adsorpsi akan terjadi karena adanya perbedaan energi potensial antara permukaan arang dan zat yang diserap. Arang aktif dapat juga menyerap sebagian bau yang tidak dikehendaki dan mengurangi jumlah peroksida sehingga memperbaiki mutu minyak (Ketaren, 2008).

Minyak yang digunakan dalam penelitian ini adalah minyak goreng kemasan. Minyak goreng tersebut digunakan untuk menggoreng bahan pangan yaitu ayam, ikan basah, ikan kering, dan tahu-tempe selama beberapa kali pengulangan menggunakan minyak goreng yang sama, temperatur yang sama, dan lama penggorenan yang sama. Sebelum dilakukan proses penggorengan, maka terlebih dahulu dilakukan analisis awal kejernihan warna minyak, kadar asam lemak bebas, dan kadar bilangan peroksida sebagai kontrol. 
Parameter kerusakan minyak secara fisik yaitu warna minyak. Kejernihan warna minyak diukur pada panjang gelombang 448 $\mathrm{nm}$ dan absorbansi menyatakan tingkat kekeruhan. Minyak goreng baru memiliki warna kuning muda dan jernih dengan nilai absorbansi rata-rata warna minyak yaitu 0,2877 dan 0,324. Absorbansi warna minyak semakin meningkat pada setiap pengulangan proses penggorengan ayam, ikan basah, ikan kering, maupun tahu tempe. Minyak jelantah bekas penggorengan ayam memiliki warna coklat kekeruhan dengan nilai absorbansi 1,446 Abs dan 1,195 Abs. Minyak jelantah bekas penggorengan ikan basah memiliki warna coklat kekeruhan dengan nilai absorbansi 1,270 Abs dan 1,254 Abs. Minyak jelantah bekas penggorengan ikan kering memiliki warna hitam gelap dengan nilai absorbansi 2,529 Abs dan 2,595 Abs. Minyak jelantah bekas penggorengan tahu-tempe memiliki warna kecoklatan dengan nilai absorbansi 0,592 Abs dan 0,658 Abs. Minyak jelantah mempunyai warna yang lebih gelap dikarenakan proses oksidasi terhadap tokoferol (Vitamin E). Oksidasi menghasilkan warna minyak menjadi kecoklatan (Irawan et al., 2013).

Kandungan asam lemak bebas dalam suatu minyak merupakan salah satu parameter penentu mutu minyak goreng. Kadar rata-rata asam lemak bebas sebelum proses penggorengan yaitu $0,1336 \%$ dan 0,1349\%. Kadar tersebut masih memenuhi standar yang disyaratkan oleh SNI yaitu maks. $0,3 \%$. Kadar asam lemak bebas semakin meningkat pada setiap pengulangan proses penggorengan. Minyak goreng bekas penggorengan ikan kering mengalami kerusakan pada proses penggorengan ke-6 dengan kadar asam lemak bebas yaitu $0,322 \%$ dan $0,326 \%$, sedangkan minyak goreng bekas penggorengan ayam, ikan basah, dan tahutempe mengalami kerusakan pada proses penggorengan ke-7 dengan rata-rata kadar asam lemak bebasnya berkisar 0,317$0,338 \%$.

Jumlah asam lemak bebas yang terdapat dalam minyak dapat menunjukan kualitas minyak, dimana semakin tinggi nilai asam lemak bebas maka semakin turun kualitasnya (Nurhasnawati et al., 2015). Asam lemak bebas terbentuk karena adanya reaksi hidrolisis dan oksidasi. Reaksi hidrolisis dapat terjadi karena terdapatnya sejumlah air dalam minyak tersebut. Dalam reaksi hidrolisis, minyak akan diubah menjadi asam-asam lemak bebas dan gliserol (Ketaren, 2008). Reaksi ini akan dipercepat dengan adanya faktorfaktor panas, air, keasaman, dan katalis (enzim). Semakin lama reaksi ini berlangsung, maka semakin banyak kadar asam lemak bebas yang terbentuk (Nurhasnawati et al., 2015).

Bilangan peroksida merupakan nilai terpenting untuk menentukan derajat kerusakan pada minyak. Kadar rata-rata bilangan peroksida sebelum proses penggorengan yaitu 3,0063 meq $\mathrm{O}_{2} / \mathrm{Kg}$ dan 3,0084 meq $\mathrm{O}_{2} / \mathrm{Kg}$. Kadar tersebut masih memenuhi standar yang disyaratkan oleh 
SNI yaitu maks. 10 meq $\mathrm{O}_{2} / \mathrm{Kg}$. Kadar bilangan peroksida semakin meningkat pada setiap pengulangan proses penggorengan. Minyak goreng bekas penggorengan ayam, ikan kering, dan tahu tempe mengalami kerusakan bilangan peroksida pada penggorengan ke-6, sedangkan minyak goreng bekas penggorengan ikan basah mengalami kerusakan pada penggorengan ke-7 dengan rata-rata kadar bilangan peroksidanya berkisar 10,868-13,369 meq $\mathrm{O}_{2} / \mathrm{Kg}$.

Peroksida terbentuk karena adanya reaksi oksidasi pada minyak. Proses oksidasi dapat berlangsung bila terjadi kontak antara sejumlah oksigen dengan minyak. Proses oksidasi dapat terjadi pada suhu kamar dan selama proses pengolahan menggunakan suhu tinggi. Oksidasi biasanya dimulai dengan pembentukan peroksida dan hidroperoksida. Tingkat selanjutnya ialah terurainya asam-asam lemak disertai konversi hidroperoksida menjadi aldehid dan keton serta asam-asam lemak bebas. Terjadinya reaksi oksidasi akan mengakibatkan bau tengik pada minyak (Ketaren, 2008). Faktor-faktor yang dapat mempercepat oksidasi pada minyak adalah suhu, cahaya, tersedianya oksigen, dan adanya logam-logam yang bersifat sebagai katalisator proses oksidasi (Nurhasnawati et al., 2015).

Kerusakan minyak selama proses penggorengan akan mempengaruhi mutu dan nilai gizi dari bahan yang digoreng. Minyak yang rusak akibat proses oksidasi akan menghasilkan bahan dengan rupa yang kurang menarik dan cita rasa yang tidak enak, serta kerusakan sebagian vitamin dan asam lemak essensial yang terdapat dalam minyak. Kerusakan minyak akibat pemanasan pada suhu tinggi akan mengakibatkan berbagai macam penyakit, misalnya diarhea, pengendapan lemak dalam pembuluh darah (arthero sclerosis), kanker, dan menurunkan nilai cerna lemak (Ketaren, 2008).

Menurut Sukmawati et al. (2014), bahwa mengkonsumsi makanan yang mengandung kadar asam lemak bebas yang cukup tinggi maka akan berakibat menaikkan kadar LDL dan menurunkan kadar HDL darah, mengurangi kemampuan tubuh mengendalikan gula darah karena dapat mengurangi respon terhadap hormon insulin. Konsumsi asam lemak yang tinggi dapat menaikkan resiko penyakit jantung.

Menurut Ketaren (2008) bahwa peroksida akan membentuk persenyawaan lipoperoksida secara nonenzimatis dalam otot usus dan mitochondria. Lipoperoksida dalam aliran darah mengakibatkan denaturasi lipoprotein yang mempunyai kerapatan rendah. Lipoprotein dalam keadaan normal mempunyai fungsi aktif sebagai alat transportasi trigeliserida; dan jika protein mengalami denaturasi akan mengakibatkan deposisi lemak dalam pembuluh darah (aorta) sehingga menimbulkan gejala atherosclerosis.

Hasil yang diperoleh dari proses pemurnian dengan menggunkan arang aktif kulit buah sukun dan arang aktif pasaran dapat dilihat pada grafik (Gambar 1 - 
Gambar 6). Kadar asam lemak bebas, bilangan peroksida, dan absorbansi warna minyak goreng bekas penggorengan ayam, ikan basah, ikan kering, dan tahu-tempe mengalami penurunan setelah dimurnikan dengan menggunakan adsorben arang aktif kulit buah sukun dan arang aktif di pasaran. Kadar yang diperoleh masih memenuhi syarat yang ditetapkan oleh SNI. Persentase rata-rata penurunan kadar asam lemak bebas pada minyak jelantah setelah dimurnikan dengan menggunakan arang aktif kulit buah sukun yaitu 51,04\% (ayam), 48,38\% (ikan basah), 52,34\% (ikan kering), dan 50,16\% (tahu tempe), sedangkan dengan menggunakan arang aktif pasaran yaitu 44,94\% (ayam), 46,71\% (ikan basah), $50,21 \%$ (ikan kering), dan 45,88\% (tahutempe). Persentase rata-rata penurunan kadar bilangan peroksida pada minyak jelantah setelah dimurnikan dengan menggunakan arang aktif kulit buah sukun yaitu 33,11\% (ayam), 29,32\% (ikan basah), $37,92 \%$ (ikan kering), dan 35,41\% (tahutempe), sedangkan dengan arang aktif pasaran yaitu 29,98\% (ayam), 16,72\% (ikan basah), 20,03\% (ikan kering), dan 30,07\% (tahu-tempe).

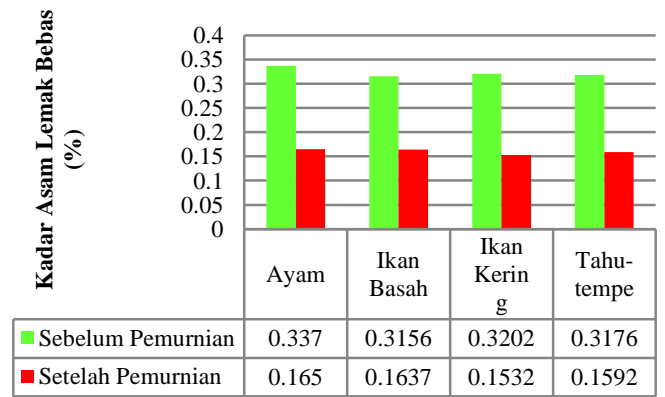

Gambar 1 Grafik Penurunan Rata-rata Kadar Asam Lemak Bebas Setelah Dimurnikan dengan Arang Aktif Kulit Buah Sukun

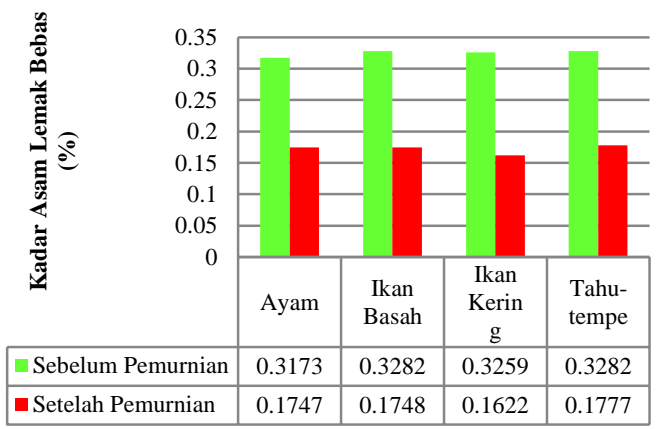

Gambar 2. Grafik Penurunan Rata-rata Kadar Asam Lemak Bebas Setelah Dimurnikan dengan Arang Aktif di Pasaran

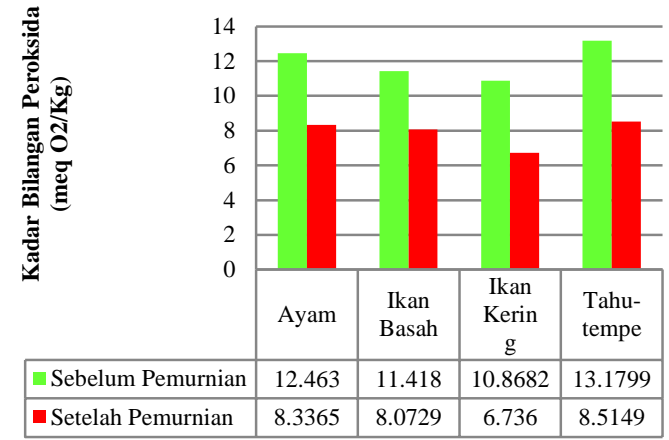

Gambar 3. Grafik Penurunan Rata-rata Kadar Bilangan Peroksida Setelah Dimurnikan dengan Arang Aktif Kulit Buah Sukun

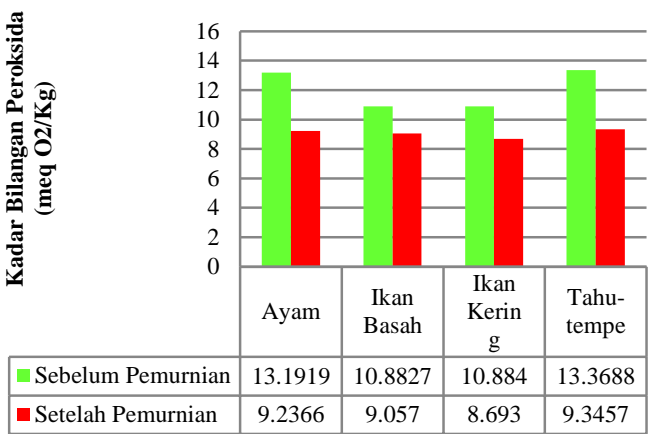

Gambar 4. Grafik Penurunan Rata-rata Kadar Bilangan Peroksida Setelah Dimurnikan dengan Arang Aktif di Pasaran

Warna minyak jelantah mengalami perubahan dari gelap menjadi jernih setelah dimurnikan dengan arang aktif kulit buah skun maupun arang aktif pasaran. Warna minyak jelantah bekas penggorengan ayam berubah dari berwarna coklat kekeruhan menjadi kuning jernih dengan penurunan nilai absorbansi dari 1,446 Abs menjadi 
0,548 Abs dengan menggunakan arang aktif kulit buah sukun serta dari 1,195 Abs menjadi 0,494 Abs dengan menggunakan arang aktif pasaran. Warna minyak jelantah bekas penggorengan ikan basah berubah dari berwarna coklat kekeruhan menjadi kuning jernih dengan penurunan nilai absorbansi dari 1,270 Abs menjadi 0,549 Abs dengan menggunakan arang aktif kulit buah sukun serta dari 1,254 Abs menjadi 0,600 Abs dengan menggunakan arang aktif pasaran. Warna minyak jelantah bekas penggorengan ikan kering berubah dari berwarna hitam gelap menjadi coklat jernih dengan penurunan nilai absorbansi dari 2,529 Abs menjadi 0,739 Abs dengan menggunakan arang aktif kulit buah sukun serta dari 2,595 Abs menjadi 0,866 Abs dengan menggunakan arang aktif pasaran. Warna minyak jelantah bekas penggorengan tahu-tempe berubah dari berwarna kecoklatan menjadi kuning muda jernih dengan penurunan nilai absorbansi dari 0,592 Abs menjadi 0,361 Abs dengan menggunakan arang aktif kulit buah sukun serta dari 0,658 Abs menjadi 0,410 Abs dengan menggunakan arang aktif pasaran.

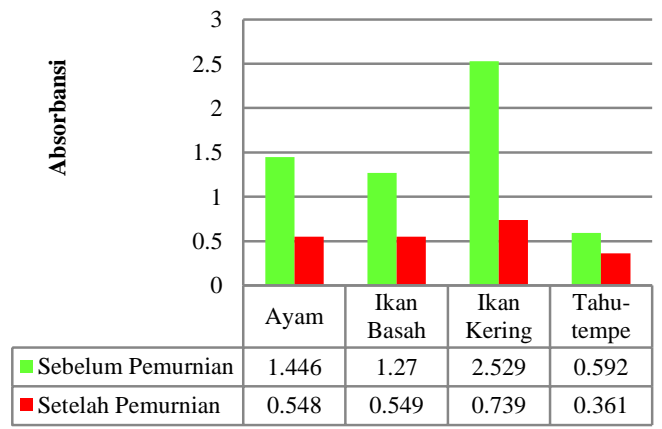

Gambar 5. Grafik Penurunan Rata-rata Absorbansi Setelah Dimurnikan dengan Arang Aktif Kulit Buah Sukun

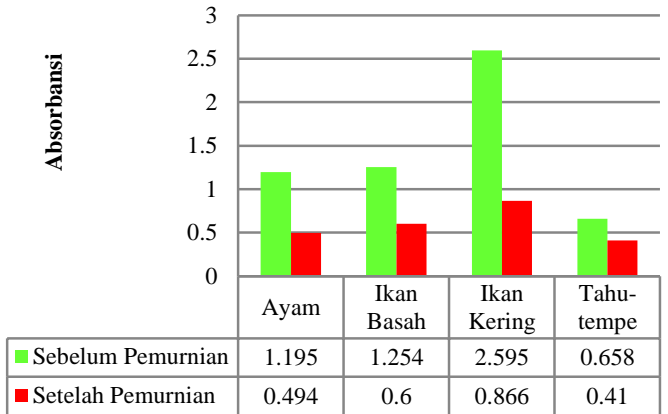

Gambar 6. Grafik Penurunan Rata-rata Absorbansi Setelah Dimurnikan dengan Arang Aktif di Pasaran

Hasil uji $T$ tidak berpasangan menunjukan bahwa kadar asam lemak bebas pada minyak jelantah dari ikan kering menunjukan adanya perbedaan yang signifikan $(p=0,017)$ antara adsorben arang aktif kulit buah sukun dan arang aktif pasaran dengan nilai $p<0,05$. Sedangkan kadar asam lemak bebas pada minyak jelantah dari ayam $(p=0,264)$, ikan basah $(p=0,015)$, dan tahu-tempe $(p=0,166)$ menunjukan tidak terdapat perbedaan yang signifikan. Kadar bilangan peroksida pada minyak jelantah dari ayam $(p=0,004)$, ikan basah $(p=0,036)$, dan ikan kering ( $p=$ $0,001)$ menunjukan bahwa terdapat perbedaan yang signifikan, sedangkan kadar bilangan peroksida pada tahu-tempe $(p=0,090)$ menunjukan tidak adanya perbedaan yang signifikan. Kadar penurunan absorbansi warna pada minyak jelantah dari ayam ( $p=0,539)$, ikan basah $(p=0,539)$, ikan kering $(p=0,244)$, dan tahu-tempe ( $p=0,059)$ menunjukan tidak terdapat perbedaan yang signifikan dengan nilai $p>0,05$. Adanya perbedaan yang signifikan dapat disebabkan karena ukuran partikel kulit buah sukun lebih kecil dan 
seragam dibandingkan dengan arang aktif tempurung kelapa yang pasaran. Menurut Haryani (2008), menyatakan bahwa semakin kecil ukuran partikel maka luas permukaan kontaknya semakin besar sehingga semakin banyak absorbat yang terserap.

\section{KESIMPULAN}

Persentase perubahan kadar asam lemak bebas dan bilangan peroksida pada minyak jelantah setelah diberi perlakuan dengan menggunakan adsorben arang aktif kulit buah sukun (Artocarpus altilis) yaitu: asam lemak bebas sebesar 51,04\% dan bilangan peroksida sebesar 33,11\% pada minyak goreng bekas penggorengan ayam, asam lemak bebas sebesar $48,38 \%$ dan bilangan peroksida sebesar $29,32 \%$ pada minyak goreng bekas penggorengan ikan basah, asam lemak bebas sebesar 52,34\% dan bilangan peroksida sebesar 37,92\% pada minyak goreng bekas penggorengan ikan kering, asam lemak bebas sebesar $50,16 \%$ dan bilangan peroksida sebesar $35,41 \%$ pada minyak goreng bekas penggorengan tahu-tempe.

Perubahan warna minyak jelantah setelah diberikan perlakuan dengan menggunakan adsorben arang aktif kulit buah sukun (Artocarpus altilis) yaitu: minyak goreng bekas penggorengan ayam dari warna coklat kekeruhan menjadi kuning jernih dengan penurunan absorbansi dari 1,446 Abs menjadi 0,548 Abs, minyak goreng bekas penggorengan ikan basah dari warna coklat kekeruhan menjadi kuning jernih dengan penurunan absorbansi dari 1,270 Abs menjadi 0,549 Abs, minyak goreng bekas penggorengan ikan kering dari berwarna hitam gelap menjadi coklat jernih dengan penurunan absorbansi dari 2,529 Abs menjadi 0,739 Abs, minyak goreng bekas penggorengan tahu tempe dari kecoklatan menjadi kuning muda jernih dengan penurunan absorbansi dari 0,592 Abs menjadi 0,361 Abs.

Penurunan kadar asam lemak bebas pada minyak jelantah dari ikan kering serta bilangan peroksida pada minyak jelantah dari ayam, ikan basah, dan ikan kering menunjukan perbedaan yang signifikan antara adsorben arang aktif kulit buah sukun (Artocarpus altilis) dengan arang aktif pasaran.

\section{UCAPAN TERIMAKASIH}

Penulis mengucapkan terimakasih kepada Laboran Jurusan Farmasi Untad yang telah membantu dalam berlangsungnya penelitian sehingga selesai sesuai dengan yang diharapkan.

\section{DAFTAR PUSTAKA}

Abdullah. (2007). Pengaruh Gorengan dan Intensitas Penggorengan Terhadap Kualitas Minyak Goreng. J Pilar Sains, 6(2), 45-50.

Aji, D. W., and Hidayat, M. N. (2011). Optimasi Pencampuran Carbon Aktive dan Bentonit Sebagai Adsorben dalam Penurunan Kadar FFA (Free Fatty Acid) Minyak Goreng Bekas Melalui Proses Adsorpsi. 1-5.

Anonim. (2012). SNI 7709:2012 (Minyak Goreng Sawit). Diperoleh dari website Badan Standarisasi Nasional. Diakses 23 Maret 2016. 
Esterlita, M. O., and Herlina, N. (2015). Pengaruh Penambahan Aktivator $\mathrm{ZnCl}_{2}, \mathrm{KOH}$, dan $\mathrm{H}_{3} \mathrm{PO}_{4}$ dalam Pembuatan Karbon Aktif dari Pelepah Aren (Arenga Pinnata). 4(1), 47-52.

Fadlia. (2016). Analisis Mutu Minyak Jelantah dengan Netralisasi Adsorben Biji Salak (Salacca Zalacca (Gaertn.) Voss) Menggunakan Parameter Bilangan Peroksida dan Asam Lemak Bebas. Skripsi. Jurusan Farmasi, Fakultas MIPA, Universitas Tadulako. Palu.

Hartini, and Yustinah. (2011). Adsorbsi Minyak Goreng Bekas Menggunakan Arang Aktif dari Sabut Kelapa. Didalam: Pengembangan Teknologi Kimia untuk Pengolahan Sumber Daya Alam Indonesia. Prosiding Seminar Nasional Teknik Kimia "Kejuangan". Yogyakarta.

Haryani, K. (2008). Potensi Zeolit dari Daerah Kemiri, Purworejo untuk Penjernihan Minyak Goreng Bekas. Teknis, 3(1), 18-23.

Irawan, C., Awalia, T. N., and Uthami, S. (2013). Pengurangan Kadar Asam Lemak Bebas (Free Fatty Acid) dan Warna dari Minyak Goreng Bekas dengan Proses Adsorpsi Menggunakan Campuran Serabut Kelapa dan Sekam Padi. Konversi, 2(2), 29-33.

Istighfaro, N. (2010). Peningkatan Kualitas Minyak Goreng Bekas dengan Metode Adsorpsi Menggunakan BentonitKarbon Aktif Biji Kelor (Moringa Oleifera Lamk.). Skripsi. Jurusan Kimia, Universitas Islam Negeri (UIN) Maulana Malik Ibrahim. Malang.

Jamilatun, S, and Setyawan, M. (2014). Pembuatan Arang Aktif dari Tempurung Kelapa dan Aplikasinya Untuk Penjernihan Asap Cair. Spektrum Industri, 12(1), 1-112.

Jaya, F. T. (2014). Adsorpsi Emisi Gas CO, NO, dan NOx Menggunakan Karbon Aktif dari Limbah Kulit Kakao (Theobroma Cacao L.) pada Kendaraan Bermotor Roda Empat. Skripsi. Jurusan Kimia, Fakultas MIPA,
Universitas Hasanuddin. Makassar.

Ketaren, S. (2008). Pengantar Teknologi Minyak dan Lemak Pangan. Jakarta: Universitas Indonesia Press.

Nasir, N. S. W. (2014). Pemanfaatan Arang Aktif Kulit Pisang Kepok (Musa Normalis) Sebagai Adsorben untuk Menurunkan Angka Peroksida dan Asam Lemak Bebas Minyak Goreng Bekas. Natural Science, 3(1), 18-30.

Nurhasnawati, H., Supriningrum, R., and . Caesariana, N. (2015). Penetapan Kadar Asam Lemak Bebas dan Bilangan Peroksida pada Minyak Goreng yang digunakan Pedagang Gorengan di Jalan A.W Sjahranie Samarinda. Manuntung, 1(1), 25-30.

Pakiding, L. M. (2014). Aktivasi Arang Tempurung Kelapa dengan $\mathrm{ZnCl}_{2}$ dan Aplikasinya dalam Pengolahan Minyak Jelantah. Skripsi. Jurusan Kimia, Fakultas MIPA, Universitas Tadulako. Palu.

Pratiwi, D. (2011). Pemanfaatan Sirup Glukosa Hasil Hidrolisa Selulosa dari Kulit Buah Sukun (Artocarpus Altilis) Dengan $\mathrm{HCl} 30 \%$ untuk Pembuatan Manisan Jambu Biji (Psidium Guajava L.) dengan Variasi Konsentrasi. Skripsi. Departemen Kimia, Fakultas MIPA, Universitas Sumatera Utara. Medan.

Priyantha, N., Lim, L. B. L., Tennakoon, D. T. B., and Mansor, N. H. M. (2013). Breadfruit (Artocarpus Altilis) Waste for Bioremediation of $\mathrm{Cu}$ (II) and Cd (II) Ions from Aqueous Medium. Ceylon Journal of Science (Physical Sciences), 17, 19-29.

Rahayu, L. H., Purnavita, S., dan Sriyana, H. Y. (2014). Potensi Sabut dan Tempurung Kelapa Sebagai Adsorben untuk Meregenerasi Minyak Jelantah. Momentum, 10(1), 47-53.

Ratnawaty, G. J., and Indrawati, R. (2016). Pengaruh Lama Waktu Kontak Kulit Pisang Kepok (Musa Acuminata L.) pada Minyak Goreng Bekas Terhadap Penurunan Kadar Asam Lemak Bebas. Jurnal Vokasi Kesehatan. II(2), 139-142. 
Rohman, A., and Sumantri. (2007). Analisis Makanan. Yogyakarta: Gadjah Mada University Press.

Sembiring, M. T., and Sinaga, T. S. (2003). Arang Aktif (Pengenalan Dan Proses Pembuatannya). Jurusan Teknik Industri, Fakultas Teknik, Universitas Sumatera Utara. USU Digital Library.

Siburian, A. M., Pardede A. S. D., and Pandia S.. (2014). Pemanfaatan Adsorben dari Biji Asam Jawa untuk Menurunkan Bilangan Peroksida pada CPO (Crude Palm Oil). Jurnal Teknik Kimia USU, 3(4), 12-17.

Sukmawati, Mustamin, and Chaerunnimah. (2014). Analisis Kandungan Kolesterol, Asam Lemak Bebas, dan Angka Peroksida pada Makanan Tradisional Khas Makassar (Coto, Konro dan Pallubasa). Media Gizi Pangan, 17(1), 1-6.

Sukriya, A. (2009). Mengolah Sukun.
Bandung: PT Sarana Ilmu Pustaka.

Taufiq, M. (2007). Pemurnian Minyak Goreng Bekas (Jelantah) Menggunakan Biji Kelor (Moringa Oleifera Lamk.). Skripsi. Universitas Islam Negeri Malang. Malang.

Wiyaningsih, F. (2010). Pengaruh Variasi Suhu Pemanasan Karbon Aktif Polong Buah Kelor (Moringa Oleifera Lamk.) Terhadap Perubahan Angka Peroksida dan Asam Lemak Bebas (FFA) pada Proses Bleaching Minyak Goreng Bekas. Skripsi. Jurusan Kimia, Fakultas Sains dan Teknologi, Universitas Islam Negeri (UIN) Maulana Malik Ibrahim. Malang.

Yuliyati, Y. B., Solihudin, Ernawati, E. E., Noviyanti, A. R., and Endah, R. (2017). Komposit Karbon Zeolit Berbahan Dasar Sekam Padi. Sains dan Terapan Kimia, 10(1), 1-5. 